\title{
IAMJ
}

INTERNATIONAL AYURVEDIC MEDICAL JOURNAL

\section{CONCEPT OF OJAS}

\author{
Abhitha.A ${ }^{1}$, Prasanna. N. Mogasale ${ }^{2}$, ArunKumar ${ }^{3}$, Nagaraj. ${ }^{4}$ \\ ${ }^{1} 2^{\text {nd }}$ year PG scholar, ${ }^{2}$ Associate Professor, ${ }^{3}$ Associate Professor, ${ }^{4}$ Professor and HOD \\ Department of Roga Nidana PG and PhD Studies \\ Sri Dharmasthala Manjunatheswara College of Ayurveda Kuthpady-574118, India
}

Corresponding Author: abhithaa0@gmail.com

\section{https://doi.org/10.46607/iamj1009062021}

(Published Online: June 2021)

Open Access

(C) International Ayurvedic Medical Journal, India 2021

Article Received: 12/05/2021 - Peer Reviewed: 03/06/2021 - Accepted for Publication: 04/06/2021

(A) Check for updates

\begin{abstract}
Increased awareness about Ayurveda and the need of Ayurveda in present society demands to understand its scope in role of immunity along with its dysfunction. Ojas is the essence present in every tissue starting from Rasa to Shukra and it is the purest substance which is omnipresent in human being. According to Ayurveda Ojas is the Dhaari as it is important in bringing about coordination among all factors responsible for sustaining life. So that its diminution leads to the cessation of life. Ojas is having the synonyms of Prana and Bala which inturn indicate the properties of Para and Apara ojas respectively. Para ojas is responsible for the life and there is no change in the form. Bala implies the physical, mental, immunological and spiritual strength. Various authors have mentioned the concept of Ojas in their own way so that there exists a controversy. In this review article I made an attempt to understand the Ojas in terms of Kriyakala so that it will be helpful in the purpose of treatment and preventive aspects.
\end{abstract}

Keywords: Ojas, Ayurveda, Kriyakala

\section{INTRODUCTION}

Ojas, the supreme essence of all seven tissues from Rasa to Sukra means vigour or essential energy of immune system. ${ }^{1}$ It is explained that Kapha in its normalcy promotes strength, lubrication, virility, immunity, resistance and stability in the form of Ojas. ${ }^{2}$ The purest substance in universe and is omnipresent in 
human being. ${ }^{3}$ According to Ayurveda Ojas is one of the most important elements for maintaining and sustaining of life. All human beings are well nourished by Ojas and its decrease leads to cessation of life. Ojas is formed during the time of fertilisation of sperm and ovum which represents the life of Kalala(mass of cells). Garbharasa refers to kalala and its essence refers to ojas or life. ${ }^{4}$ Ojas is located in the Hridaya and is also related to ten vessels i.e. Ojas spreads all over the body through the ten vessels. Here the Hrudaya (heart) refers to Urohrudaya. ${ }^{5}$ When all body parts of foetus formed, Ojas manifested by its symptoms. In other words, we can say that this Ojas before pregnancy remains in ovum and sperm. In the $8^{\text {th }}$ month of pregnancy sthira property of Ojas is not established completely. Therefore, Ojas is unstable in $8^{\text {th }}$ month because exchange of Ojas takes place through blood vessels from mother to foetal heart and from foetal to mothers' heart. When ojas is moving from foetus to mother, the foetus born at this time will be prone to develop infectious diseases. Due to which delivery in this month is to be considered dangerous. ${ }^{6} \mathrm{Ojus}$ is constantly nourished by essence of body tissues.

Materials and Methods: A detailed study is based on literature review of classical information, published research works and modern literature. The collected information is analysed and presented in systemic way with objective to establish relation of Ojo dosha with Kriyakala

\section{Types of Ojas}

According to Acharya Chakrapani 2 types of Ojas found in the body. They are as follows.

\section{Para ojas}

Para ojas is the prime one which is located at Hridaya. It is in the purest form. Its Ashta bindhu $(2.5 \mathrm{ml})$ in pramana. ${ }^{7}$ Chakrapani states that para Ojas is Alpa pramana(subtle). The Para ojas is responsible for life and death therefore the diminution in its volume will give rise to grave disease and instantaneous death of that person. There is no change in the form of it. Therefore, the protection of Para ojas is having prime importance.

\section{Apara ojas}

Apara ojas which is supportive and located at heart and ten vessels. It is half Anjali (96ml) in measurement.
This ojas is similar to quality of Shleshma(phlegm) so called Shleishmika ojas. Apara ojas influences functioning of tissues. It is of different form such as Ushma, Prakrita Shleshma, Rasa, Jeeva shonitha, Dhatunam tejasi. $^{8}$

\section{a) Ushma:}

Jatharagni (digestive fire) is the main principle substance responsible for disease and health. During its normalcy is responsible for longevity, complexion, strength, health, enthusiasm, well built, lusture, ojas, temperature, other fires (bhutagni and dhatwagni) and other vital functions. ${ }^{9}$ The functions we can see in the Gastric juice which is a digestive fluid formed within the stomach lining. With a PH between 1 and 3. These gastric acid plays a key role in digestion of proteins by activating digestive enzymes, which together break down the long chains of amino acids of proteins. In conditions like hypochlorhydria and achlorhydria there is deficiency or absence of hydrochloric acid in the stomach. Stomach secretions are made up of hydrochloric acid, several enzymes and a mucus coating that protects the lining of stomach. ${ }^{10}$ This potentially leading to problems as the disinfectant properties of the gastric lumen are decreased. In such condition there is a greater risk of infections of the digestive tract such as infection with Vibrio or helicobacter bacteria.

\section{b) Shleshmani Prakrita}

The Prakrita sleshma is bala (strength) and it in turn is ojas. This normal Shleshma shows the qualities of unctuousness, softness, coldness, immobility, sliminess, sweetness. ${ }^{11}$ The same functions we can see in Mucosal barriers which separate the external environment from the body's internal milieu. These selectively permeable barriers prohibit passage of bacteria and toxins while permitting flux of water, ions and solutes, including nutrients.

\section{c) Rasa}

Rasa dhatu, the food when digested completely with the help of digestive fire forming the essence of entire process of digestion and metabolism and is capable of traversing the minute pores of the body. It provides the sense of satisfaction, nourishment and supplies nourishment to Raktadhatu. ${ }^{12}$ 
Blood plasma is a yellowish liquid component of blood that holds the blood cells of whole blood in suspension. It's the liquid part of the blood that carries cells and proteins throughout the body. It is mostly water (upto $95 \%$ by volume) and contains important dissolved proteins (6-8\%) (e.g. serum albumin, globulins and fibrinogen) glucose, clotting factors, electrolytes, hormones, carbon-di-oxide, oxygen. It plays a vital role in an intravascular osmotic effect that keep electrolyte concentration balanced and protects the body from infection and other blood disorders. ${ }^{13}$

\section{d) Jeeva shonitha}

Jeeva shonitha-Having the function of nourishment and sustenance of the body. Its diminution and excess is because of shonitha ${ }^{14}$. It also keeps the individual live ${ }^{15}$. This we can see in blood, the formed elements with the clotting factors. Formed elements are the erythrocytes, leukocytes and the thrombocytes with the following functions respectively that is the red blood cells which functions in oxygen transport, the white blood cells function in immunity and the platelets functions in blood clotting.

The other clotting factors are fibrinogen, prothrombin, factor V, VII, IX, X, XI, XII as well as protein C and S and antithrombin whereas liver sinusoidal endothelial cells produce factor VIII and von Willebrand factor. ${ }^{16}$

\section{e) Dhatunam thejasi- Nutrition}

The essence of all Dhatus from Rasa to Shukra which is nothing but the Ojas which provide strength. Food is responsible for health, complexion and hence the Ojas. In classics its explained under Nitya sevaniya dravya that shastika shali, madhu (honey) as the carbohydrate source, mudga (greengram), yava (barley) as protein , Saindhava lavana, Amalaka as minerals and salts, Sarpi as fat. ${ }^{17}$ Avoiding excessive fasting and the above mentioned kinds of food helps to increase the Ojas. Nutrition is the science that interprets the nutrients and other substances in food in relation to maintenance, growth, reproduction, health and disease of an organism, it includes ingestion, absorption, assimilation, biosynthesis, catabolism and excretion. Nutrients are compounds in food essential to life and health providing us with energy, the building blocks for repair and growth of substance necessary to regulate chemical process.
These are six major nutrients, carbohydrates, lipids, proteins, vitamins, minerals and water.

\section{Etiological factors for Abnormalities of Ojas $^{18}$}

Various factors which are responsible for the decreases of Ojas has been mentioned in our Ayurveda classics. This we can categorise into Sahaja, Kalaja and Yuktikrita.

Sahaja karana:- Hereditary strength is present in the body and mind since birth or naturally. The constitutional immunity is genetically determined ability of a living being.

Kalaja karana:- Seasonal or periodic etiology depends on season. In aadana kala where the strength is less as the sun is in Utharayana by its nature too hot and the Vata dosha also get aggravates by its nature leads to the decrease in strength. Also, we can consider the age factor where childrens due to the immature organs and systems of body, delicate body and mind, limited tolerance to the physical and psychological stress. Also, in old age groups there is depletion of tissues, reduced tolerative power so that strength get reduced.

Yuktikruta karana:- There are certain factors which affect the mind and body during their life time that is acquired during their life time. Acquired reasons are both mental and physical trauma or injury to vital parts, excessive physical exercise, fasting for a long period, constant worry, drinking strong wines, excessive indulgence in sex, fear leads to the aggravation of Vata dosha and hence there is depletion of tissues.

\section{Abnormalities of Ojas}

The condition that may arise as a result of metabolic abnormalities leading to Ojo visramsa, Ojo vyapad and Ojo kshaya the 3 types of abnormalities of ojas. Ojas is responsible for wellbeing and diseases ranging from physical and mental fatigue to acute and chronic, mild and severe type of diseases. ${ }^{19}$

\section{Ojo Visramsa}

The displacement from its own position i.e. here the ojas is dispersed by vitiated vata from its own siteHeart. Dispersed ojas results in altered physiology but never results in death all of a sudden. First stage of ojo dosha where the dosha sramsana is the basic event in this stage, which results in hinderance to normal functioning or mild obstruction in organs /body channels/ 
tissues/ manas/sense organs. Here the improper functioning is responsible for clinical manifestation. Visramsa in terms of kriya kala explains the stage of accumulation (Sanchaya) to stage of manifestation (Vyaktha) of Kriyakala. Here from stage of accumulation, stage of aggravation and stage of spread there is flow of dosha. From stage of localisation to stage of manifestation there occurs the obstruction of functioning and manifestation of diseases. ${ }^{20}$

\section{Ojo Vyapat}

Second stage of ojo dosha where the symptoms mentioned in vyapanna are just continuation of visramsa itself and exhibits clinical manifestation in a different manner ie, Upadrava. Ojo vyapat avastha is as a result of interaction of a particular dosha and particular dhatu (body tissue). Vyapanna in terms of kriyakala can be the complication ie, the symptoms mentioned in it is just continuation of Visramsa. ${ }^{21}$

Symptoms of ojo vyapad are stiffness and feeling heaviness in the body, swelling, change in complexion or discoloration, exhaustion, drowsiness or stupor, sleeplessness. $^{22}$

\section{Ojokshaya}

Ojokshaya follows Ojo vyapat in which all the symptoms of Ojovisramsa and Ojo vyapat will be there. Oja $k$ shaya denotes reduction in its normal scale of Ojas it must be para Ojas as its diminution only is responsible for death. Diminution in Ojas indicates Pratyakheya. Symptomatology are fainting, decrease of muscle bulk, delirium, death, mental disturbance specially in judgement, physical and mental debility, fear, dryness or roughness, emaciation of body. ${ }^{23}$

\section{Oja dosha chikitsa}

Rasayana chikitsa is a unique branch of Ayurveda for attaining the excellent Rasadi dhatus. As Ojas is the essence of all seven tissues. For the Ojo dosha it could be the proper treatment. So that one should give up all the unwholesome diet and regimens to enjoy the full span of his life. ${ }^{24}$

\section{DISCUSSION}

Health is the state of wellbeing and if we are desiring a good health then it is necessary to eliminate the accumulated dosha in the form of ama and hence focusing on producing the ojas, which is the essential life energy. Ojas is the essence of dhatus which gives strength to the body, improves immunity power and takes care of wellbeing of the body. It is present all through the body like ghee exists in the milk or honey exists in the flower. Ojas is considered as the most refined result of digestion, metabolism, absorption and assimilation. One's physical mental and spiritual strength depends on the Ojas. The nature of ojas will differ from person to person depending on the constitution, Agni, Satva etc. Basically, the ojas is of 2 types ie., para ojas and Apara ojas ${ }^{25}$.There occurs progressive diminution of properties of ojas and is termed as ojo dosha. Description of ojodosha and kriyakala is unique in Susruta Samhita. Ojo visramsa denotes stage of accumulation to stage of manifestation of disease. Ojo vyapat denotes stage of complication of a disease. Ojo visramsa and Ojo vyapat are basically diminution of properties of Ojus and are related with apara ojus only. Oja kshaya refers to pramanata kshaya of Ojus and is related to para ojas which leads to the ultimate death. Improving the strength of the body is known as Urjaskara. Rasayana is the means to obtain the body tissues of high quality. In other words, it is the means to promote all the transformative process in the body in production of the purest essence called Ojas.

\section{CONCLUSION}

Ojas is one's life energy when it is normal and adequate implies the immunity and in its diminutive condition results in weakness, fatigue and ultimately to disease.

Sole intent of description of Ojo dosha is to explain the prognosis. The relation of ojo dosha and Kriyakala is very particular in Susrutha samhitha. That is the Ojo visramsa denotes the stage of accumulation to stage of manifestation of disease. Ojo Vyapat denotes the stage of complications.

\section{REFERENCES}

1. Agnivesha, Charaka, Drdhabala, Charaka Samhitha, edited by Vaidya Jadavji Trikamji Acharya, Sutrasthana,17/75, edition reprint, Varanasi: Chaukamba Orientalia; 2011. p.105.

2. Agnivesha, Charaka, Drdhabala, Charaka Samhitha edited by Vaidya Jadavji Trikamji Acharya, 
Sutrasthana,18/51, edition reprint, Varanasi: Chaukamba Orientalia; 2011.p.109.

3. Vagbhata, Ashtanga Hrudayam, edited by Pt Hari Sadasiva sastri Paradakara, Sutrasthana,11/37-38, edition reprint. Varanasi: Chaukamba Sanskrit Sansthan; 2011.P.189.

4. Agnivesha, Charaka, Drdhabala, Charaka Samhitha. Edited by Vaidya Jadavji Trikamji Acharya, Sutrasthana,30/10, edition reprint, Varanasi: Chaukamba Orientalia; 2011.p.185.

5. Agnivesha, Charaka, Drdhabala, Charaka Samhitha edited by Vaidya Jadavji Trikamji Acharya, Sutrasthana,17/1-2, edition reprint,Varanasi: Chaukamba Orientalia ; 2011. p.99.

6. Agnivesha, Charaka, Drdhabala, Charaka Samhitha edited by Vaidya Jadavji Trikamji Acharya, Shareerasthana,4/24, edition reprint, Varanasi: Chaukamba Orientalia; 2011. p.320,321.

7. Agnivesha, Charaka, Drdhabala, Charaka Samhitha edited by Vaidya Jadavji Trikamji Acharya, Shareerasthana,4/24, edition reprint, Varanasi Chaukamba Orientalia; 2011. p.184.

8. Arunadatta, Ashtanga Hrudayam, edited by Pt Hari Sadasiva sastri Paradakara, Sutrasthana,11/37-38, edition reprint. Varanasi: Chaukamba Sanskrit Sansthan; 2011.P.189.

9. Agnivesha, Charaka, Drdhabala, Charaka Samhitha edited by Vaidya Jadavji Trikamji Acharya, Chikitsasthana,15/3-4, edition reprint, Varanasi: Chaukamba Orientalia; 2011. p.512.

10. Medically reviewed by Saurabh sethi- written by Megan Dix, RN, BSN https://www.healthline.com/health/hypochlorhydria

11. Agnivesha, Charaka, Drdhabala, Charaka Samhitha edited by Vaidya Jadavji Trikamji Acharya, Sutrasthana,17/117, edition reprint, Varanasi: Chaukamba Orientalia; 2011. p.105.

12. Sushrutha, Sushrutha Samhitha, edited by Vaidya Jadavji Trikamji Acharya and Narayan Ram Acharya Kavyatirtha, Sutrasthana, 14/3, edition reprint, Varanasi: chaukamba Sanskrit Sansthan; 2013. P.59.

13. Sagar Aryal, https://microbiologyinfo.com/difference between serum and plasma

14. Sushrutha, Sushrutha Samhitha, edited by Vaidya Jadavji Trikamji Acharya and Narayan Ram Acharya Kavyatirtha, Sutrasthana, 14/9, edition reprint, Varanasi: chaukamba Sanskrit Sansthan; 2013. P.60

15. Sushrutha, Sushrutha Samhitha, edited by Vaidya Jadavji Trikamji Acharya and Narayan Ram Acharya
Kavyatirtha, Sutrasthana, 15/4, edition reprint, Varanasi: chaukamba Sanskrit Sansthan; 2013. P.67.

16. American society of hematology https://www.hematology.org/education/patients/blood basics

17. Agnivesha, Charaka, Drdhabala, Charaka Samhitha edited by Vaidya Jadavji Trikamji Acharya, Sutrasthana,5/12, edition reprint, Varanasi: Chaukamba Orientalia; 2011. p.38.

18. Agnivesha, Charaka, Drdhabala, Charaka Samhitha edited by Vaidya Jadavji Trikamji Acharya, Sutrasthana,11/36, edition reprint, Varanasi: Chaukamba Orientalia; 2011.p.74.

19. Sushrutha, Sushrutha Samhitha, edited by Vaidya Jadavji Trikamji Acharya and Narayan Ram Acharya Kavyatirtha, Sutrasthana, 15/24, edition reprint, Varanasi: chaukamba Sanskrit Sansthan; 2013. P.72

20. Sushrutha, Sushrutha Samhitha, edited by Vaidya Jadavji Trikamji Acharya and Narayan Ram Acharya Kavyatirtha, Sutrasthana, 15/24, edition reprint, Varanasi: chaukamba Sanskrit Sansthan; 2013. P.72

21. Sushrutha, Sushrutha Samhitha, edited by Vaidya Jadavji Trikamji Acharya and Narayan Ram Acharya Kavyatirtha, Sutrasthana, 15/24, edition reprint, Varanasi: chaukamba Sanskrit Sansthan; 2013. P.72.

22. Dr.P. Himasagara Chandra Murthy, Madhukosha, Madhava Nidana,43/18 $3^{\text {rd }}$ ed. Chaukamba Sanskrit series Varanasi; 2013. P.89.

23. Sushrutha, Sushrutha Samhitha, edited by Vaidya Jadavji Trikamji Acharya and Narayan Ram Acharya Kavyatirtha, Sutrasthana, 15/24, edition reprint, Varanasi: chaukamba Sanskrit Sansthan; 2013. P.72.

24. Agnivesha, Charaka, Drdhabala, Charaka Samhitha edited by Vaidya Jadavji Trikamji Acharya, Chikitsasthana,2/3, edition reprint, Varanasi: Chaukamba Orientalia; 2011. p.381.

25. Arunadatta, Ashtanga Hrudayam, edited by Pt Hari Sadasiva sastri Paradakara, Sutrasthana,11/37-38, edition reprint. Varanasi: Chaukamba Sanskrit Sansthan; 2011.P.189.

\section{Source of Support: Nil Conflict of Interest: None Declared}

How to cite this URL: Abhitha. A: Concept Of Ojas. International Ayurvedic Medical Journal \{online\} 2021 \{cited June, 2021\} Available from: http://www.iamj.in/posts/images/upload/1218_1222.pdf 